\title{
Sexual Dimorphism in Relation to Structural Changes in Renal Cortex in Different Age Groups: Possible Role of Endogenous SCs
}

\author{
Original \\ ${ }^{1,3}$ Maha Baligh Zickri, ${ }^{2}$ Amany ElSayed Hammoud \\ Article \\ ${ }^{1}$ Departments of Medical Histology \& Cell Biologya, ${ }^{2}$ Anatomy and Embryologyc, Faculty \\ of Medicine, Cairo University, Egypt \\ ${ }^{3}$ Faculty of Oral and Dental Medicine, Future University, Egypt (FUE)
}

\begin{abstract}
Background: Chronic kidney disease (CKD) is an inevitable process which might be the major cause of death in senile age. In certain diseases male gender is a risk factor. The mitotic division of resident SCs might be stimulated by cellular injury and contribute to the restoration of damaged cells.

Aim of study: The current study is designed to study the sexual dimorphism in relation to structural changes in the renal cortex in prepubertal, pubertal and postpubertal age groups of rat. In addition, possible role of endogenous stem cells (SCs). Materials and methods: Thirty albino rats were divided into three groups, Pre-pubertal, pubertal and post-pubertal each was subdivided into two subgroups male and female respectively. The body weight (BW), kidney weight (KW), cross sectional area $(\mathrm{CA})$ and serum creatinine (sC) were determined. Kidney sections were subjected to histological, histochemical, immunohistochemical, morphometric and statistical studies.

Results: BW and glomerular area values recorded age related changes. While $\mathrm{KW}, \mathrm{CA}$, sC, count of dark nuclei, area of collagen, thickness of tubular basement membrane, count of proliferation marker proved age and sex related changes.

Conclusion: Progressive age related increase in BW, KW, CA, sC and glomerular area (GA) was found, that became reciprocal for the GA in postpubertal rats due to atrophy. Elevated $\mathrm{sC}$, enhanced apoptosis, fibrosis and thickened tubular basement membrane (tBM) and reduced cellular proliferation were detected. Enhanced SCs migration in response to injury were more noticeable in male postpubertal rats.
\end{abstract}

Received: 04 September 2018, Accepted: 28 November 2018

Key Words: Kidney, PCNA, postpubertal, prepubertal, pubertal.

Corresponding Author: Amany ElSayed Hammoud, M.D., Faculty of medicine Cairo University Egypt Kasrelaini, Egypt, Tel.: +20 1020364428, E-mail: dramanyhamoud@gmail.com

ISSN: 1110-0559, Vol. 42, No. 1

\section{INTRODUCTION}

Chronic kidney disease (CKD) is an inevitable process which might be the major cause of death in senile age and poor countries. Most of cases of CKD further progressed to end stage case, in which renal transplant is not an affordable option ${ }^{[1]}$.

Age changes in many organs and systems in human body are also related to sex which might explain the predominance of certain diseases in male or female. As in old male cardiovascular disease, while in old female autoimmune disease are overwhelming ${ }^{[2]}$.

Rodents are the ideal model for aging as well as for age-related diseases for many reasons, their short life span compared to human make it easier for studying different modalities ${ }^{[3]}$. National Institute of aging assume that the aging curve for rats aged 6, 30 months rats correspond roughly to humans in their third, sixth decades of life respectively ${ }^{[4]}$.

Sexual dimorphism which means gender difference between male and female, was found in rat, mice and human species $^{[5]}$. It sometimes explains why in certain diseases male gender is a risk factor, where female hormones give an additional protection against ${ }^{[6]}$. Postmenopausal reduction of female hormones can be related to the female becoming vulnerable to such diseases same like male ${ }^{[7]}$.

Recently, studies have proved that some types of glomerulonephritis are affected also by gender ${ }^{[8]}$. There have been many studies regarding decrease in renal function and glomerular filtration rate, nephrons segmentation, structural features of the proximal tubular epithelium affected by gender ${ }^{[9]}$. Preclinical trials on the kidney in experimental animal models revealed the importance of sex in these trials even for non aged animals ${ }^{[10]}$.

It was suggested that the mitotic division of resident stem cells (SCs) might be stimulated by cellular injury ${ }^{[11]}$. Intra renal resident cells have stem- or progenitor-like characteristics and contribute to the restoration of damaged tubular epithelial cells ${ }^{[12]}$.

In the current study our aim was to prove the hypothesis 
of sexual dimorphism in relation to structural changes in the renal cortex in prepubertal, pubertal and postpubertal age groups of rat. In addition, possible role of endogenous SCs was studied.

\section{MATERIALS AND METHODS}

\section{Animals}

The current study was carried out on 30 albino rats. The rats were obtained from Animal House of Kasr -Alainy, Faculty of Medicine, Cairo University. Rats were housed for one week for environmental adaptation under standard laboratory conditions at $22-24{ }^{\circ} \mathrm{C}$ with 12 hours light dark cycle. They were fed on a constant adequate nutrition diet and allowed free access to drinking water ad libitum. The experimental work was conducted in accordance with the guidelines of the Committee of Laboratory Animals at Kasr-Alainy.

Rats were divided into three groups, each was subdivided into two subgroups, each subgroup (5 rats) was kept in a separate cage as follows:

1. Pre-pubertal (Pre) group: 10 rats 4-6 weeks old ${ }^{[13]}$. weighing 80-100 gram (g), subdivided into two subgroups 5 males and 5 females.

2. Pubertal (Pub) group: 10 rats 4-6 months old $^{[14]}$ weighing $150-180 \mathrm{~g}$, subdivided into two subgroups 5 males and 5 females.

3. Post -pubertal (Post) group: 10 rats 20-24 months old ${ }^{[13]}$ weighing 250-280 g 5 males and 5 females.

All rats were sacrificed by cervical dislocation ${ }^{[15]}$. after IP injection of phenobarbitone sodium $(60 \mathrm{mg} / \mathrm{kg})^{[16]}$ after 1 week of housing for environmental adaptation.

\section{Methods}

1. Determination of the body weight (BW) of rats in the different subgroups.

2. Before sacrifice, blood was collected from the tail veins of animals belonging to each subgroup using capillary tubes for assessment of serum creatinine (sC).

3. Median abdominal incision was performed, both kidneys were excised and fixed in 10\% formol saline for 24 hours.

4. Determination of the kidney weight $(\mathrm{KW})$ and kidney cross sectional area $(\mathrm{CA})(\mathrm{cm} 2)$ of rats in the different subgroups.

5. Paraffin blocks were prepared and $5 \mu \mathrm{m}$ thick sections were subjected to the following studies:

\section{Histological study:}

Hematoxylin and eosin (H\&E) stain ${ }^{[17]}$.

Masson's trichrome stain ${ }^{[18]}$.

\section{Histochemical study:}

Periodic acid Schiff (PAS) reagent ${ }^{[18]}$.

\section{Immunohistochemical study:}

$0.1 \mathrm{ml}$ of the primary antibody $(\mathrm{Ab})$ proliferating cell nuclear antigen (PCNA ${ }^{[19]}$ mouse monoclonal (PC 10) proliferation marker was applied at a concentration 200 microgram $(\mu \mathrm{g}) / \mathrm{ml}$ for 60 minutes. Tonsil sections are used as positive control which give a brown coloration. On the other hand, one of the kidney sections was used as a negative control by passing the step of applying the primary $\mathrm{Ab}$.

Cluster of differentiation (CD)105 immunostaining the marker for mesenchymal stem cells $(\mathrm{MSCs})^{[20]} 0.1 \mathrm{ml}$ prediluted primary antibody (CD105) rabbit polyclonal $\mathrm{Ab}(\mathrm{ab} 27422)$ and incubate at room temperature in moist chamber for 60 minutes. Tonsil used as positive control specimens. Cellular localization is the cell membrane. On the other hand, one of the kidney sections was used as a negative control by passing the step of applying the primary antibody.

\section{Morphometric study:}

Using Leica Qwin 500 LTD (Cambridge, UK) computer assisted image analysis system, glomerular area (GA) $(\mu 2)$ and count of dark nuclei (DN) were performed in H\&E stained sections. In addition, the area of collagen fibers and the thickness of the tubular basement membrane (tBM) were measured in Masson's trichrome and PAS stained sections. The count of PCNA +ve nuclei (N) and area of CD105 +ve cells were done in immunostained sections. The measurements were done in 10 fields using interactive measurements menu.

\section{Statistical study:}

Quantitative data were summarized as means and standard deviations and compared using one-way analysisof-variance (ANOVA). Any significant ANOVA was followed by post hoc Tukey test to detect which pairs of groups caused the significant difference. P-values $<0.05$ were considered statistically significant $(\mathrm{sig})^{[21]}$ Calculations were made on Statistical Package of Social Science (SPSS) software version 16.

\section{RESULTS}

\section{Mean $B W, K W, C A$ and $s C$ induced changes}

The mean BW estimated revealed a sig increase in the Post group compared to the other 2 groups and in Pub group versus Pre group. Also, the mean KW, the mean CA and the mean $\mathrm{sC}$ measured denoted a sig increase in the Post group compared to the other 2 groups and in the Pub group compared to the Pre group only. In addition, a sig increase was proved in the Pub and Post male subgroups compared to the corresponding female subgroups as regards mean $\mathrm{KW}$, mean $\mathrm{sC}$ and mean $\mathrm{CA}$, the latter showed sig increase in Pre male versus the corresponding female (Table 1, Histograms 1a, 1b, 1c, 1d). 


\section{Histological changes}

\section{Changes in the $G A$ and count of $D N$}

Sections in the renal cortex of rats representing Pre group showed apparently small sized glomeruli, some dark nuclei among the lining of glomerular capillaries and the lining cells of the renal tubules (Fig 1a, 1b). Pub group revealed apparently average sized glomeruli and few dark nuclei among the lining of glomerular capillaries and the lining cells of the renal tubules (Fig 1c, 1d). Post male subgroup demonstrated some distended glomeruli, others atrophic and multiple dark nuclei among the glomerular capillaries among (Fig 1e). Post female subgroup recruited distended and atrophic glomeruli, but some dark nuclei among the lining of glomerular capillaries and the lining cells of the renal tubules (Fig 1f). Widening of the Bowman's space was noticed in the last group.

The mean GA estimated revealed a sig increase in the Pub group compared to the Pre and Post groups. While, the mean count of DN a sig increase was found in the Post male subgroup compared to all other subgroups and in Post female compared to Pub female (Table 2, Histograms 2a, 2b).

\section{Changes in the collagen content}

Sections in the renal cortex of rats representing Pre group showed dense collagen deposition among the tubules (Fig 2a, 2b). Pub group revealed fine collagen fibres between the tubules (Fig 2c, 2d). Post group demonstrated fibrosed shrunken glomeruli (Fig 2e, 2f).

The mean area of collagen detected recorded a sig increase in the Post group compared to the Pre and Pub groups and in the Pre group compared to Pub group. In addition, a sig increase was proved in the Post male subgroup compared to the corresponding female subgroup (Table 2, Histogram 2c).

\section{Age and sex induced histochemical changes}

\section{Changes in the tBM thickness}

Sections in the renal cortex of rats representing: Pre and Pub groups showed obvious reaction in the tubular BM and apparently normal brush border (Fig 3a, 3b. 3c, 3d). Post group revealed thickened parts of the tubular BM and apparently normal brush border (Fig 3e, 3f).

The mean tBM detected indicated a sig increase in the Post group compared to Pre and Pub groups and in Post male compared to the corresponding female. While, a sig increase was found in the Pub group compared to Pre female subgroup (Table 2, Histogram 2d).

\section{Age and sex induced immunohistochemical changes}

\section{Changes in the count of PCNA +ve N}

Sections in the renal cortex of rats representing Pre group showed some PCNA +ve nuclei (Fig 4a, 4b). Pub group revealed few +ve nuclei (Fig4c, 4d). Post male subgroup demonstrated accidental +ve nuclei (Fig 4e) and Post female subgroup recruited few +ve nuclei (Fig 4f).

The mean count of $+\mathrm{ve} \mathrm{N}$ estimated revealed a sig decrease in the Post male subgroup compared to all other subgroups and in the Post female subgroup to Pre group. While, in the Pub male subgroup a sig decrease was found compared to the Pre group and in Pub female compared to Pre female.

\section{Changes in the count of CD105 +ve cells}

Sections in the renal cortex of rats representing Pre group showed some + ve spindle cells (Fig 5a, 5b). Pub group revealed few + ve spindle cells (Fig 5c, 5d). Post male subgroup demonstrated some +ve spindle cells (Fig 5e). Post female subgroup recruited few +ve spindle cells (Fig 5f). The spindle cells were found around blood vessels and glomerular capillaries in all groups.

The mean count of + ve cells denoted a sig increase in Pre group and Post male subgroup versus Pub group and in Pre female subgroup versus Post female subgroup in addition. (Table 3, Histograms 3a, 3b). 


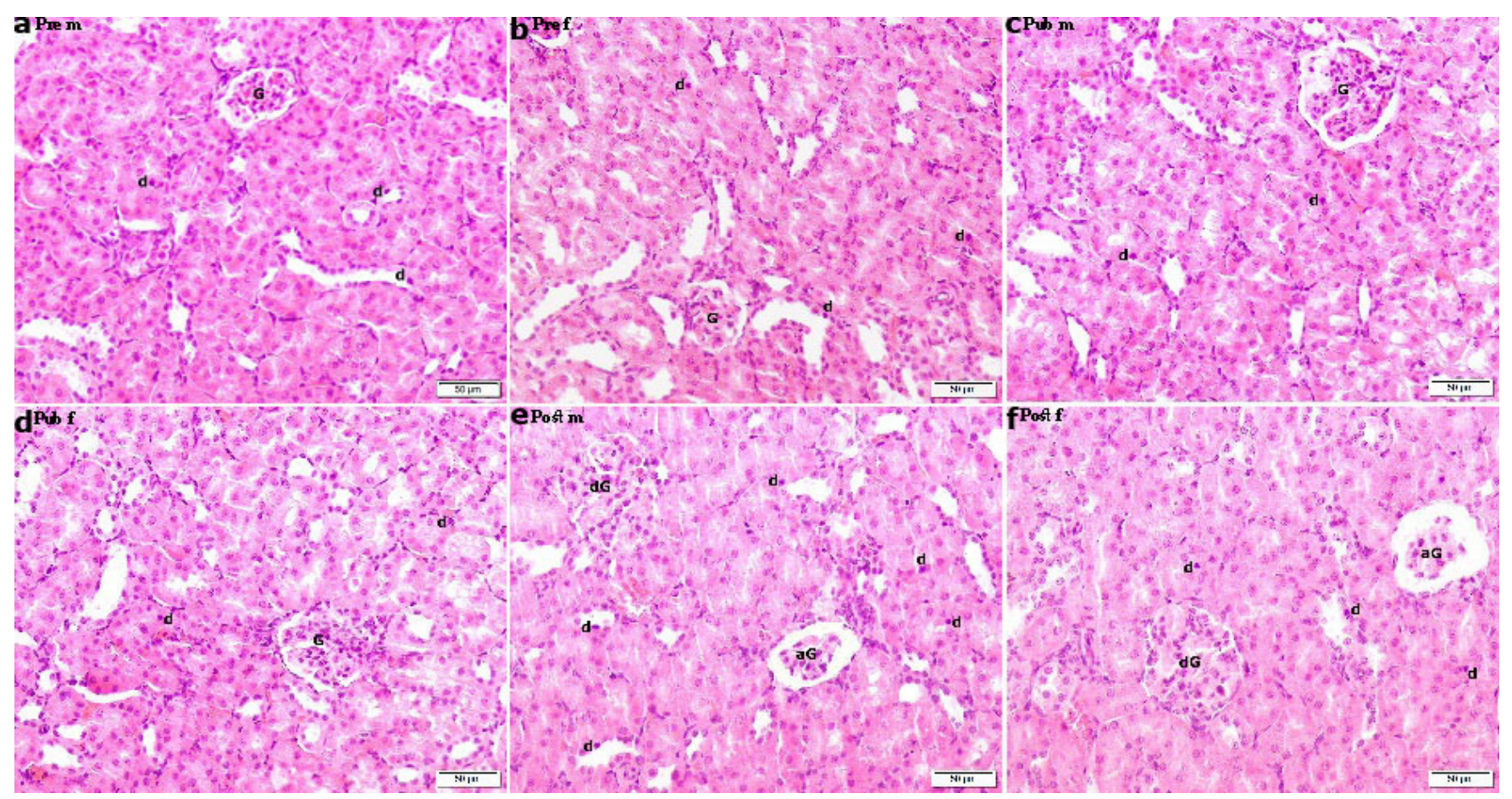

Fig 1: H\&E (X200): staining of the rat renal cortex showing: a) and b) apparently small sized glomerulus (G), some dark nuclei (d) in Pre male and female. c) and d) apparently average sized glomerulus (G), few dark nuclei (d) in Pub male and female. e) a distended glomerulus (dG), an atrophic one (aG) and multiple dark nuclei (d) in Post male. f) a distended glomerulus (dG), an atrophic one (aG) and some dark nuclei (d) in Post female.

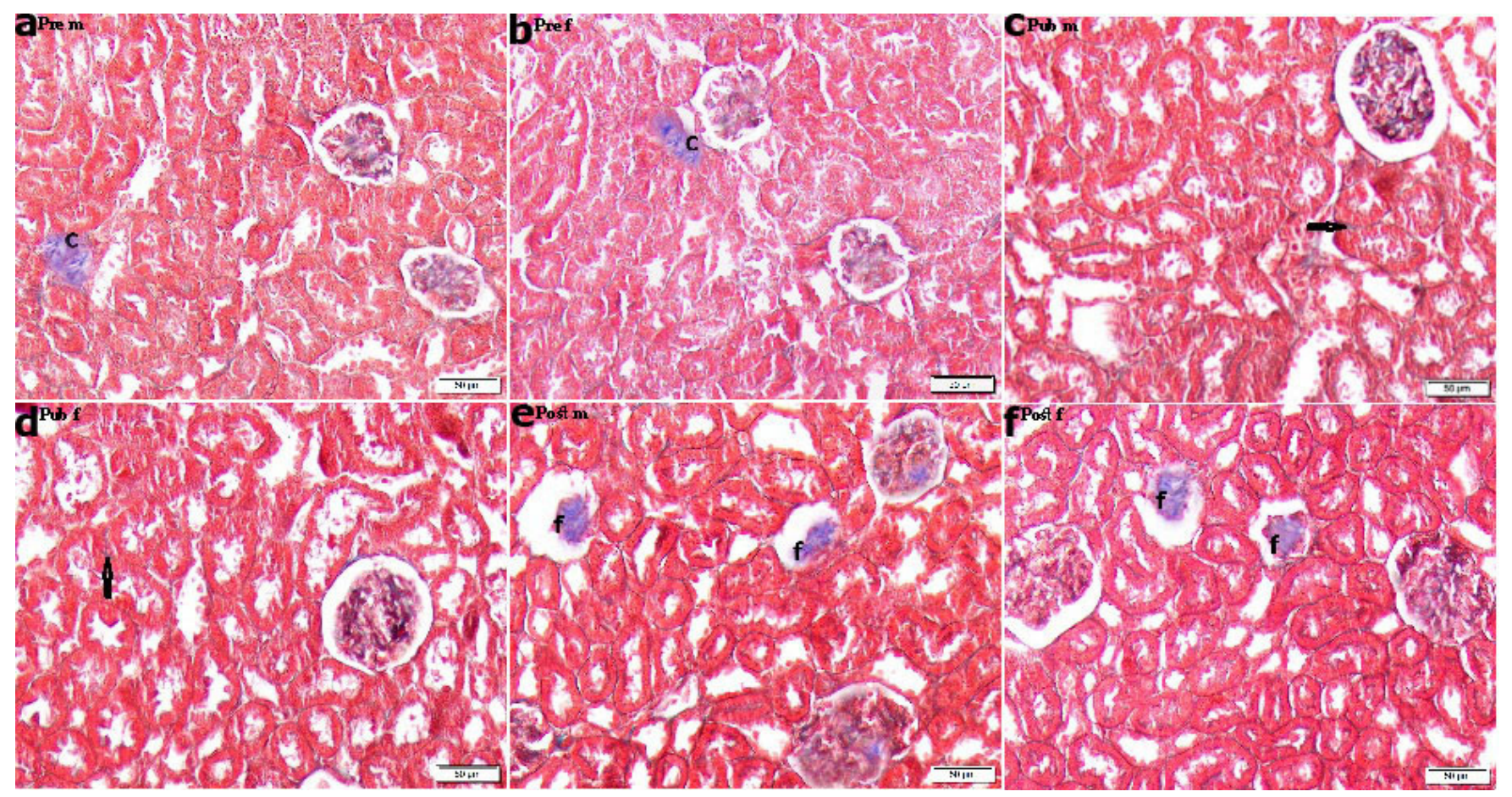

Fig 2: Masson's trichrome (X200): staining of the rat renal cortex showing a) and b) dense collagen (C) deposition among the tubules in Pre male and female. c) and d) fine collagen fibres (arrow) between the tubules in Pub male and female. e) and f) fibrosed shrunken glomeruli (f) in Post male and female. 


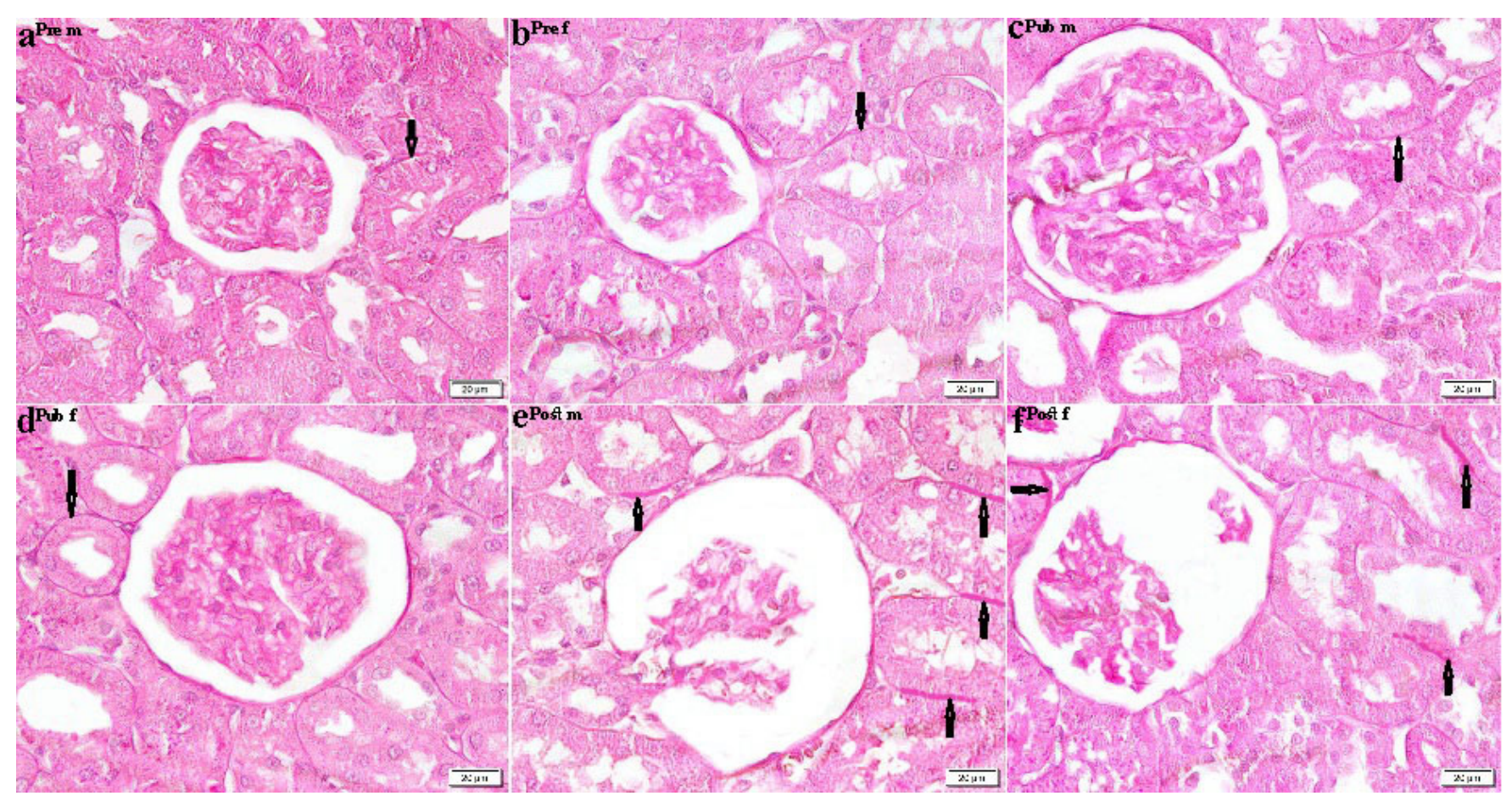

Fig 3: PAS staining(X400): of the rat renal cortex showing: a), b), c) and d) obvious reaction in the $t$ BM (arrows) in Pre, Pub male and female. e) and f) thickened parts of the tBM (arrows) in Post male and female.

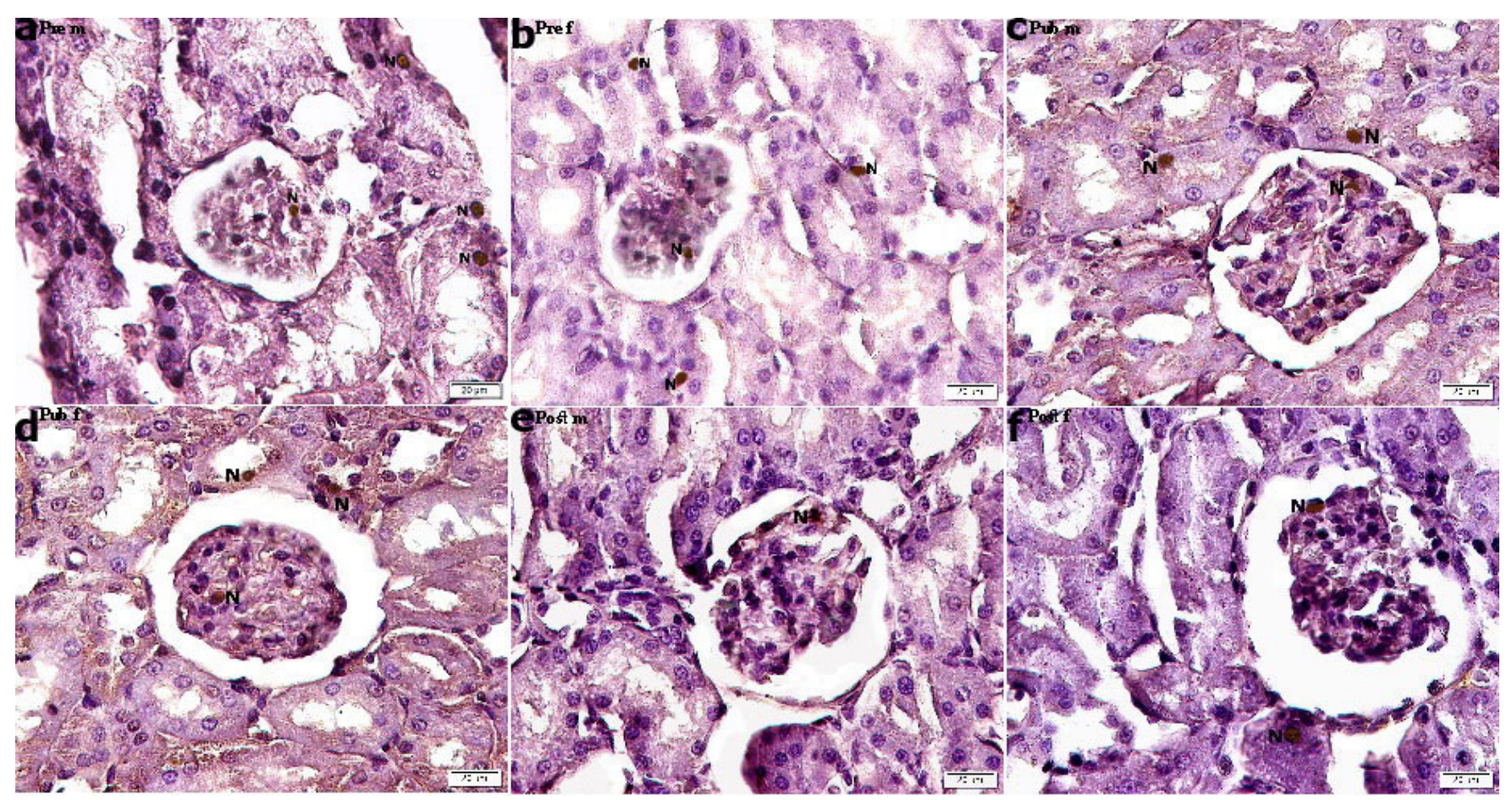

Fig 4: PCNA immunostaining (X400) of the rat renal cortex showing: a) and b) some +ve nuclei (N) in Pre male and female. c) and d) few +ve nuclei (N) in Pub male and female. e) a +ve nucleus (N) in Post male. f) two +ve nuclei (N) in Post female. 


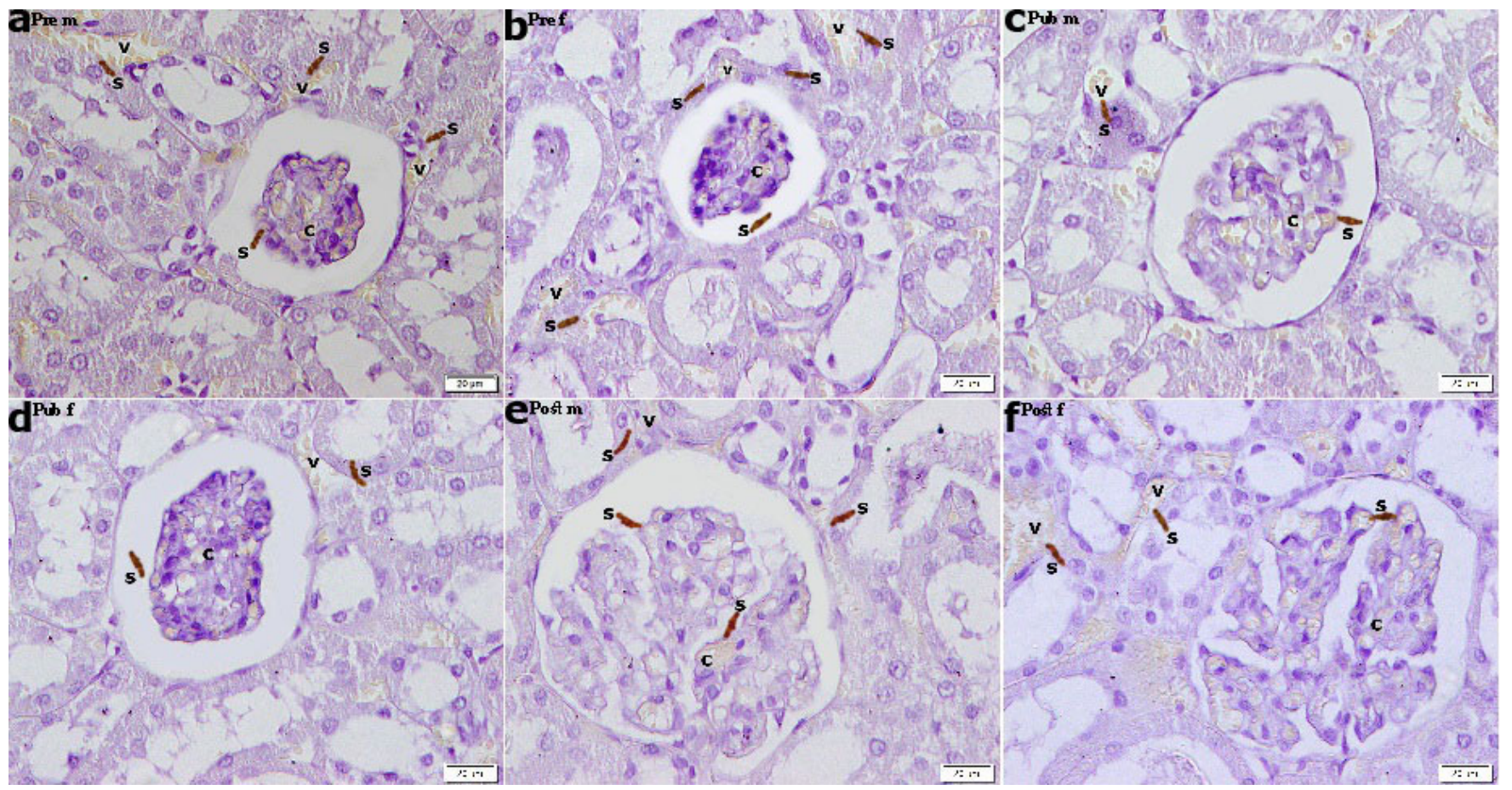

Fig 5: CD105 immunostaining (X400) of the rat renal cortex showing: a) and b) some +ve spindle cells in Pre male and female (s). c) and d) few +ve spindle cells in Pub male and female (s). e) some +ve spindle cells in Post male (s). f) few +ve spindle cells in Post female (s). The spindle cells (s) were found around blood vessels (v) and glomerular capillaries (c).

Table 1: Mean BW, KW, CA and sC in different subgroups

\begin{tabular}{|c|c|c|c|c|}
\hline Subgroup & BW & KW & $\mathrm{CA}$ & $\mathrm{sC}$ \\
\hline Pre-pubertal male & $89.00 \pm 5.72$ & $0.67 \pm 0.04$ & $0.63 \pm 0.02^{\wedge \wedge}$ & $0.24 \pm 3.59$ \\
\hline Pre-pubertal female & $90.00 \pm 3.59$ & $0.64 \pm 0.05$ & $0.54 \pm 0.01$ & $0.22 \pm 3.59$ \\
\hline Pubertal male & $160.00 \pm 13.48^{* *}$ & $1.76 \pm 0.21 \bullet \wedge$ & $1.00 \pm 0.16 \bullet \bullet \wedge$ & $0.41 \pm 3.59 \bullet \bullet$ \\
\hline Pubertal female & $171.0 \pm 20.30 * *$ & $1.41 \pm 0.16 \bullet \bullet$ & $0.93 \pm 0.22 \bullet \bullet$ & $0.35 \pm 3.59 \bullet \bullet$ \\
\hline Post-pubertal male & $260.00 \pm 29.71 *$ & $2.54 \pm 0.61 \bullet \wedge$ & $1.65 \pm 0.30^{\bullet \wedge}$ & $0.75 \pm 3.59 \bullet \wedge$ \\
\hline Post-pubertal female & $269.00 \pm 28.96^{*}$ & $2.14 \pm 0.50 \bullet$ & $1.34 \pm 0.21 \bullet$ & $0.54 \pm 3.59 \bullet$ \\
\hline
\end{tabular}

* significant (sig) $P<0.001$ (Post versus Pre and Pub)

** $\operatorname{sig} P<0.001$ (Pub versus Pre)

- sig $P<0.001$ (Post versus Pre and Pub)

•• sig $P<0.001$ (Pub versus Pre)

^ sig $P<0.001$ (Post male versus Post female) $P<0.05$ (Pub male versus Pub female)

$\wedge$ sig $P<0.01$ (Pre male versus Pre female)
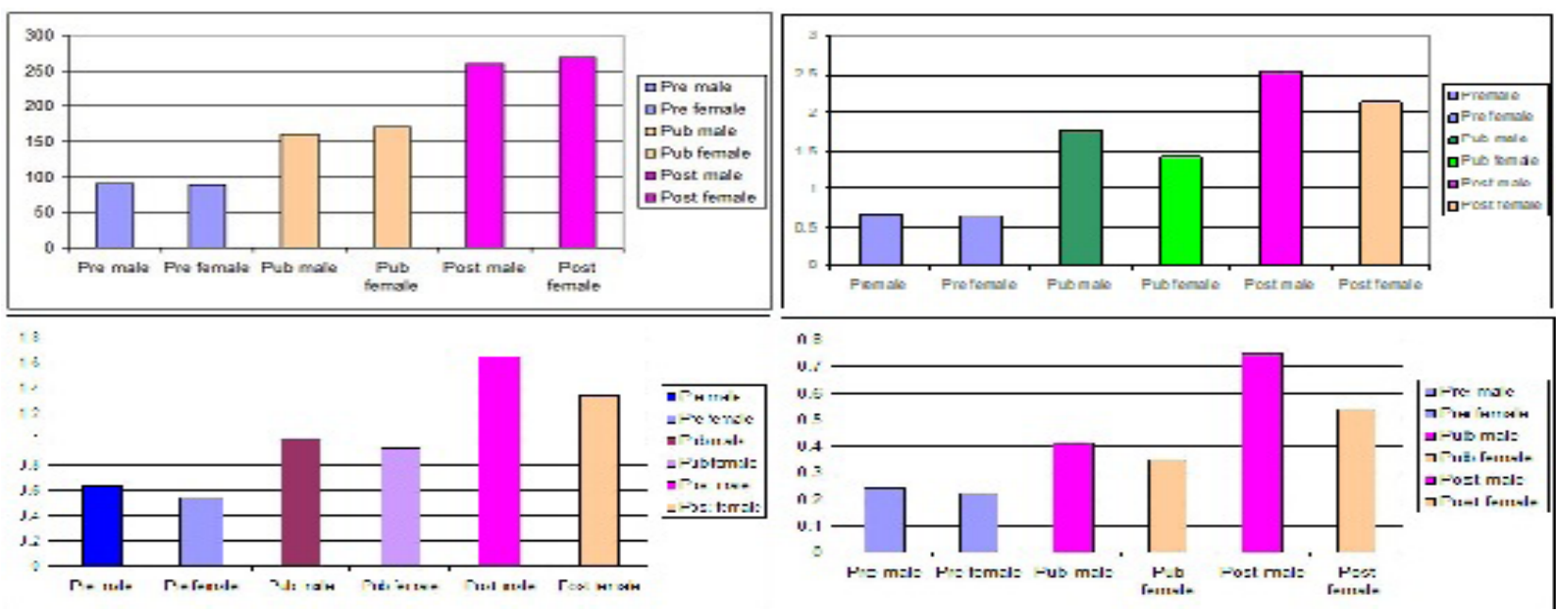

Histogram 1: a) Mean BW. b) Mean KW. c) Mean CA. d) Mean sC. 
Table 2: Mean GA, count of DN, area of collagen fibers and tBM thickness in different subgroups

\begin{tabular}{|c|c|c|c|c|}
\hline Subgroup & GA & Count of DN & Area of collagen fibers & tBM thickness \\
\hline Pre-pubertal male & $1332.30 \pm 34.59$ & $2.50 \pm 0.13$ & $5.94 \pm 1.01 \cdot-$ & $0.43 \pm 0.02$ \\
\hline Pre-pubertal female & $1159.38 \pm 59.72$ & $2.40 \pm 0.09$ & $5.71 \pm 0.95=$ & $0.31 \pm 0.03$ \\
\hline Pubertal male & $2533.36 \pm 77.48^{*}$ & $1.90 \pm 0.05$ & $2.29 \pm 0.08$ & $0.59 \pm 0.07 \bullet \bullet$ \\
\hline Pubertal female & $2229.06 \pm 65.30^{*}$ & $1.80 \pm 0.04$ & $2.02 \pm 0.22$ & $0.57 \pm 0.05 \bullet \bullet$ \\
\hline Post-pubertal male & $1607.89 \pm 29.71$ & $4.20 \pm 0.31^{\wedge}$ & $10.21 \pm 1.63=\#$ & $1.63 \pm 0.14 \bullet \#$ \\
\hline Post-pubertal female & $1285.04 \pm 26.96$ & $2.90 \pm 0.08^{\wedge \wedge}$ & $8.39 \pm 2.05 \cdot$ & $1.17 \pm 0.09 \bullet$ \\
\hline
\end{tabular}

* sig $P<0.001$ (Pub versus Pre and Post)

^ sig $P<0.001$ (Post male versus Pre and Pub) $P<0.01$ (versus Post female)

$\wedge$ sig $P<0.05$ (Post female versus Pub female)

-sig $P<0.001$ (Post versus Pre and Pub) $\quad \# P<0.05$ (Post male versus Post female)

- sig $P<0.001$ (Pre versus Pub)

- sig $P<0.001$ (Post versus Pub and Pre) $\quad \# P<0.01$ (Post male versus Post female)

$\bullet P<0.01$ (Pub versus Pre female).
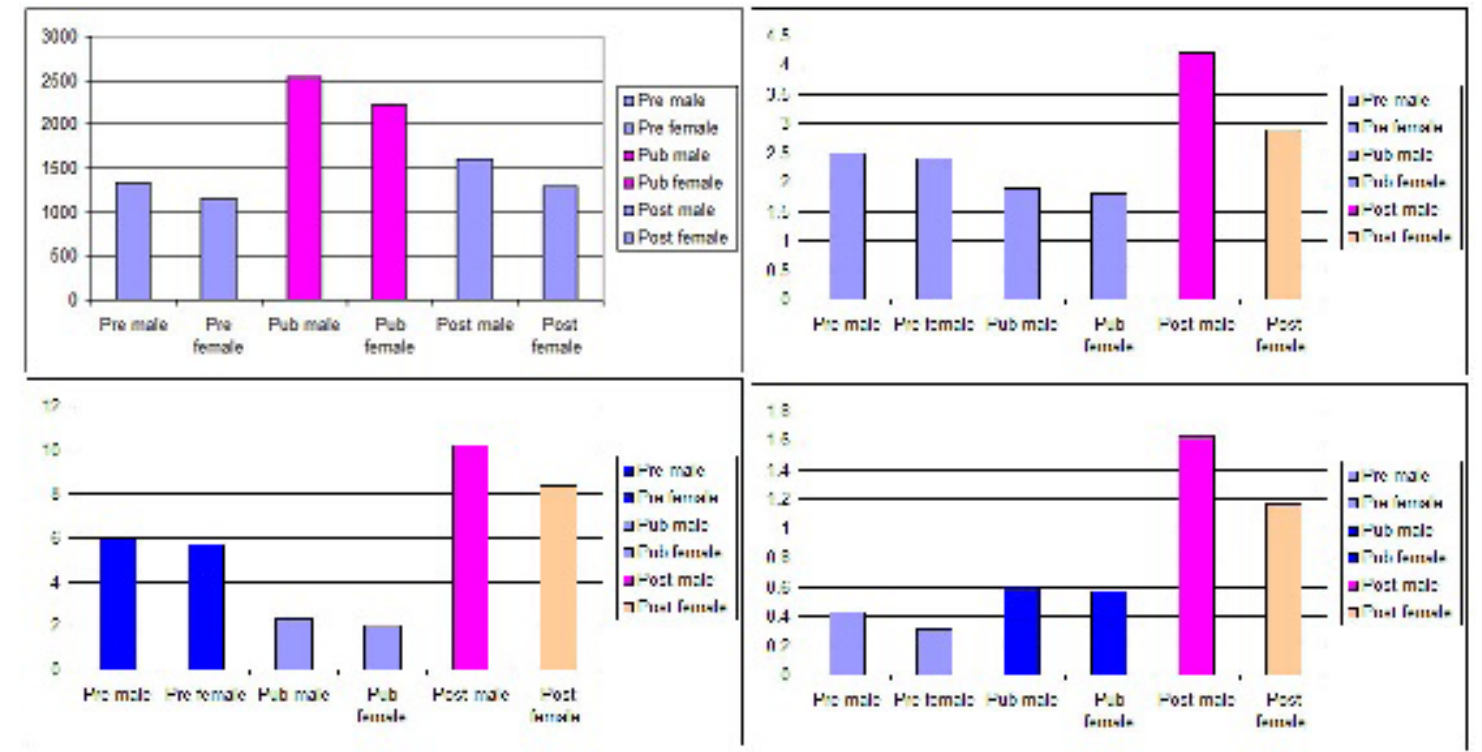

Histogram 2: a) Mean GA.b)Mean count of DN. c) Mean area of collagen fibers. d) Mean tBM.

Table 3: Mean count of PCNA +ve nuclei and CD105 +ve cells in different subgroups

\begin{tabular}{lcc}
\hline Subgroup & Count of PCNA +ve N & Count of CD105+ve cells \\
\hline Pre-pubertal male & $3.60 \pm 0.59$ & $3.30 \pm 0.19 \cdot$ \\
Pre-pubertal female & $3.80 \pm 0.70$ & $3.60 \pm 0.219 \cdot$ \\
Pubertal male & $2.50 \pm 0.08^{\wedge}$ & $1.80 \pm 0.04$ \\
Pubertal female & $2.80 \pm 0.30^{\wedge \wedge}$ & $1.60 \pm 0.02$ \\
Post-pubertal male & $1.10 \pm 0.21^{*}$ & $3.20 \pm 0.71$ \\
Post-pubertal female & $2.10 \pm 0.46^{* *}$ & $2.30 \pm 0.10$ \\
\hline
\end{tabular}

* $\operatorname{sig} P<0.001$ (Post male versus Pre and Pub) $P<0.05$ (versus Post female)

** sig $P<0.001$ (Post female versus Pre)

${ }^{\wedge} \operatorname{sig} P<0.01$ (Pub male versus Pre female) $P<0.05$ (versus Pre male)

$\wedge \wedge$ sig $P<0.05$ (Pub female versus Pre female)

-sig $P<0.01$ (Pre male versus Pub)

. sig $P<0.001$ (Pre female versus Pub female) $P<0.01$ (versus Pub male) $\mathrm{P}<0.05$ (versus Post female)

- sig $P<0.01$ (Post male versus Pub female) $P<0.05$ (versus Pub male) 

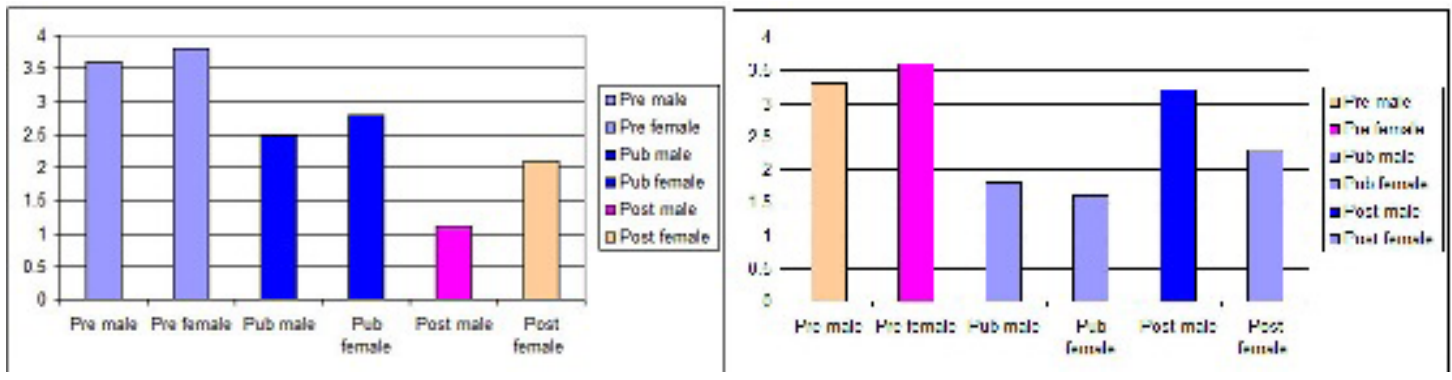

Histogram 3: a) Mean count of PCNA +ve N. b) Mean count of CD105 +ve cells.

\section{DISCUSSION}

The present study investigated the dimensional, histological, histochemical, immunohistochemical and morphometric changes that may develop in the kidney in relation to age and sex.

The mean BW estimated in the current work revealed a sig increase in the Post group compared to the Pre and Pub groups. In agreement, It was stated that the BW increased with age until 18 months then started to decrease after ${ }^{[22]}$. In human, BW was related to changes in age and sex hormones as ovarian failure during the late perimenopause is associated with a sharp rise in serum $\mathrm{FSH}$, which coincides with the onset of visceral adiposity ${ }^{[23]}$.

The mean KW and mean CA in the present study denoted a sig increase in the Post group and, in the Pub group compared to the Pre group. In addition, a sig increase was proved in the Pub and Post male subgroups compared to the corresponding female. In support, It was confirmed with previous findings ${ }^{[24]}$. Moreover in the present study mean CA showed a sig increase in Pre male versus the corresponding female, in opposite the presence of any sex difference was denied in the pre group ${ }^{[24]}$. In human, kidney volume changes with gender only and not by age were correlated in healthy donors ${ }^{[25]}$. On the other hand, a larger cohort of 1344 kidney donors were studied and it was pointed out that kidney volume is nearly stable till age of 50 then decline after ${ }^{[26]}$.

The mean $\mathrm{sC}$ measured in the current study denoted a sig increase in the Post group compared to the other two groups and in the Pub group compared to the Pre group. In agreement, it was recorded that elevated $\mathrm{sC}$ in Pub group than Pre one, and assumed that this elevation is related to greater muscle mass ${ }^{[27]}$. In addition, a sig increase was proved in the current study in Pub and Post male subgroups compared to the corresponding female subgroups. In accordance, many studies proved that males have a more accelerated age-related functional decline in kidney function than females which might be due to lower estrogen level ${ }^{[28]}$.

Glomerular changes, in Pre group the glomeruli appeared small, in the Pub group average sized and in the Post group some were distended or atrophic. The previous results were confirmed by a sig increase in the mean GA in the Pub group compared to the Pre and Post groups. Going with, glomerular atrophy and collapse were reported in aged rats ${ }^{[29]}$. It was stated stated that the rat renal corpuscle diameter continuously increased from age 3 to 30 months $^{[30]}$ and the incidence of glomerulosclerosis was confirmed in 20 months aged rats ${ }^{[31]}$. In human, it was stated that glomerulosclerosis may develop in the kidney with age progression ${ }^{[32]}$.

The mean count of DN a sig increase was found in the present work in the Post male subgroup compared to all other subgroups and in Post female compared to Pub female, indicating enhanced apoptosis in Post male subgroup. In support, increased apoptotic cell death that was proved in senile male rodents can count for injury in aged kidney ${ }^{[33]}$. It was confirmed that the aging is associated with oxidative stress ${ }^{[34]}$.

Collagen content, increased deposition was detected in the Pre group, while in the Post group fibrosed glomeruli were seen, these changes were evidenced by a sig increase in the mean area of collagen in the Post group compared to the Pre and Pub groups and in the Pre group compared to Pub group. Moreover, a sig increase was proved in the Post male subgroup compared to the corresponding female. Similarly, slight interstitial fibrosis was noticed after 24 months ${ }^{[30]}$. It was pointed out that extracellular matrix synthesis and degradation must be in balance to maintain tissue homeostasis and any deviation of this balance lead to interstitial fibrosis ${ }^{[35]}$.

It was added that extracellular matrix accumulation especially collagen is an important factor in pathogenesis of chronic renal disease, leading to renal fibrosis ${ }^{[36]}$. In addition, it was proved that fibrosis resulting from repeated injury is a cumulative process by age. It was added that testosterone has more potent effect in collagen expression than estrogen that may lead to sexual dimorphism.

In human, it was documented that aging is accompanied with extracellular protein accumulation and replacement of functioning kidney parenchyma by fibrosis ${ }^{[32]}$.

On the other hand, interstitial fibrosis was noticed from age 3 to 12 months $^{[30]}$. It was declared that collagen expression is stimulated by estrogen ${ }^{[38]}$ which was confirmed by a sig increase in the collagen content found in female adult rats than corresponding male rats, with no sex difference in young and old rats ${ }^{[24]}$. 
Thickened tBM was observed in Post group, confirmed by a sig increase in the mean tBM thickness in the Post group, in addition to a sig increase found in Post male compared to the corresponding female and in Pub group compared to Pre female subgroup. Thickening and undulation of the tBM was postulated in old rats ${ }^{[39]}$. In human, obvious thickening of tBM was reported in aged cases, which was symptomless in more than $30 \%{ }^{[40]}$.

The mean count of PCNA +ve N estimated revealed a sig decrease in the Post male subgroup compared to all subgroups and in the Post female subgroup to Pre group. Going with, it was found that genes associated with cell proliferation become altered in 24 months old mice and associated with reduced tissue proliferation ${ }^{[41]}$. It was added that cellular proliferation was decreased in aged overiectomized rats $^{[42]}$.

While, in the Pub male subgroup a sig decrease was found compared to the Pre group and in Pub female compared to Pre female. In accordance, it was commented on inability of tubular epithelial cells of adult kidneys for de novo nephrogenesis ${ }^{[43]}$. Enhanced cellular proliferation was confirmed in young rats ${ }^{[44]}$.

On the contrary, no sig difference was found in +ve staining of nuclear PCNA between young and aged mice although the number of + vely stained nuclear PCNA were more in young mice than in aged mice ${ }^{[45]}$.

The mean count of CD105 +ve cells denoted a sig increase in Pre group and Post male subgroups versus Pub group and in Pre female subgroup versus Post female subgroup in addition. Concomitantly, it was proved that the postnatal SCs were described as fibroblastic cells that exhibit a surface marker profile positive for CD73, CD44, CD90 and CD105. They were defined by the International Society for Cellular Therapy as MSCs ${ }^{[46]}$. Resident SCs function was reported to maintain and repair tissues and if depleted this can cause premature tissue aging ${ }^{[47]}$. Additionally, in case of tissue injury that occurs usually with aging, expansion of progenitor population can occur resulting in an increase in the number ${ }^{[48]}$. Recently, it was proved that young rat MSCs experienced robust tissue genesis $^{[49]}$. It was confirmed that reduced regenerative capacity of aged stem cells hampers organ regeneration, but not migration due to injury ${ }^{[50]}$.

\section{CONCLUSION}

Progressive age related increase in $\mathrm{BW}, \mathrm{KW}, \mathrm{CA}, \mathrm{sC}$ and GA was found, that became reciprocal for the GA in Post group due to atrophy. Disturbed histophysiology was established in the form of elevated $\mathrm{sC}$, enhanced apoptosis, fibrosis and thickened tBM as well as reduced cellular proliferation. Enhanced MSC migration in response to injury were more noticeable in male Post group. So, it is recommended that close attention should be focused on sex and gender differences regarding kidney disease progression, risk factors and prescription patterns.

\section{COMPLIANCE WITH ETHICAL STANDARDS}

\section{CONFLICT OF INTEREST}

None of the authors have a conflict of interest to report.

\section{LIST OF ABBREVIATION}

+ve: Positive.

Ab: Antibody.

ANOVA: Analysis of variance.

BW: Body weight.

C: Centigrade.

CA: Cross sectional area.

CD: Cluster of differentiation.

CKD: Chronic kidney disease.

CM2:Centimeter.

DN: Dark nuclei.

GA: Glomerular area.

Gm: gram.

H\&E: Haematoxylin and eosin.

KW: Kidney weight.

PAS:Periodic acid Shiff.

PCNA: Proliferating cell nuclear antigen

Post:Post-pubertal.

Pre:Pre-pubertal.

Pub:Pubertal.

$\mathrm{sC}$ : Serum creatinin.

SCs: Stem cells.

Sig: Significant.

SPSS: Statistical Package of Social Science.

tBM: Tubular basement membra

\section{REFERENCES}

1. Bello AK, Levin A, Tonelli M, Okpechi IG, Feehally J, Harris D, Jindal K, Salako BL, Rateb A, Osman MA et al .Assessment of Global Kidney Health Care Status. JAMA 2017; 317(18): 1864-1881.

2. Kennedy BK, Berger SL, Brunet A, Campisi J, Cuervo AM, Epel ES, Franceschi C, Lithgow GJ, Morimoto RI, Pessin JE et al. Geroscience: linking aging to chronic disease. Cell 2014; 159 (4): 709-713

3. Mitchell SJ, Scheibye-Knudsen M, Longo DL, de Cabo R .Animal models of aging research: implications for human aging and age-related diseases. Annus Rev Anim Biosci. 2015; (3): 283303. 
4. Walker EM, Nillas MS, Mangiarua EI, Cansino S, Morrison RG, Perdue RR, Rice KM. Ageassociated changes in hearts of male Fischer 344/ Brown Norway F1 rats. Ann Clin Lab Sci 2006; 36(4): 427-438

5. Rosenfeld CS, Trainor BC. Environmental Health Factors and Sexually Dimorphic Differences in Behavioral Disruptions. Curr Environ Health Rep 2014;1(4): 287- 301.

6. Starling S. Renal physiology: the sexually dimorphic kidney. Nat Rev Nephrol 2017;13(10): 596

7. Wijkstrom J, Jayasumana C, Dassanayake R, Priyawardane N, Godakanda N, Siribaddana S, Ring A, Hultenby K, Soderberg M, Elinder CG et al. Morphological and clinical findings in Sri Lankan patients with chronic kidney disease of unknown cause (CKDu): Similarities and differences with Mesoamerican Nephropathy. PloS One 2018;13 (3): e0193056-0193074.

8. Riispere Z, Laurinavicius A, Kuuderberg A, Seppet E, Sepp K, Ilmoja M, Luman M, Kolvald M, Auerbach A, Ots-Rosenberg M. IgA nephropathy clinicopathologic study following the Oxford classification: Progression peculiarities and gender-related differences. Medicina (Kaunas) 2016; 52(6): 340-348.

9. Stanchev S, Iliev A, Malinova L, Landzhov B, Hinova-Palova D .Histological study on the postnatal alterations in the rat kidney. Scientific Medica 2017; 49 (1): 26-30.

10. Miller LR, Marks C, Becker JB, Hurn PD, Chen WJ, Woodruff T, McCarthy MM, Sohrabji F, Schiebinger L, Wetherington CL et al .Considering sex as a biological variable in preclinical research. FASEB J 2017; (1): 29-34

11. Kim J, Kim JI, Na YK, Park KM Intra-renal slow cell-cycle cells contribute to the restoration of kidney tubules injured by ischemia/reperfusion. Anat Cell Biol 2011b; 44(3): 186-193

12. 12. Kim K, Park BH, Ihm H, Kim KM, Jeong J, Chang JW, Cho YM Expression of stem cell marker CD133 in fetal and adult human kidneys and pauci-immune crescentic glomerulonephritis. Histol Histopathol 2011a; 26 (2): 223-232.

13. Quinn R .Comparing rat's to human's age: how old is my rat in people years? Nutrition 2005; 21(6): 775-777.

14. Sengupta P.The Laboratory Rat: Relating Its Age With Human's. Int J Prev Med 2013; 4(6): 624630 .
15. Iranpour FG, Kheiri S. Coadministration of calcium chloride with lead acetate can improve motility of cauda epididymal spermatozoa in Swiss white mice. Int J Reprod BioMed 2016;14(2): 141-144.

16. Ozmen J, Bobryshev YV, Lord RS, Ashwell KW. Identification of dendritic cells in aortic atherosclerotic lesions in rats with diet induced hypercholesterolaemia. Histol Histopathol 2002; 17: 223-237.

17. Kiernan JK.Histological and Histochemical methods. In: Theory and practice. 3rd ed, Arnold Publisher, London, New York and New Delhy 2001; 111-162.

18. Bancroft JD, Gamble M. Carbohydrates. In: Theory and Practice of Histological Techniques, sixth edition. Elsevier Health Sciences, Churchill Livingstone, Edinburgh, London, Oxford, New York, Philadelphia, St Louis, Sydney and Toronto 2008; 161-186.

19. Fu X, He Y, Wang X, Peng D, Chen X, Li X, Wan Q. MicroRNA-16 Promotes Ovarian Granulosa Cell Proliferation and Suppresses Apoptosis Through Targeting PDCD4 in Polycystic Ovarian Syndrome. Cell Physiol Biochem 2018; 48(2): 670-682.

20. Xiong ZH, Wei J, Lu MQ, Jin MY, Geng HL. Protective effect of human umbilical cord mesenchymal stem cell exosomes on preserving the morphology and angiogenesis of placenta in rats with preeclampsia. Biomed Pharmacother 2018;105: 1240-1247.

21. Emsley R, Dunn G, White I (2010) Mediation and moderation of treatment effects in randomized controlled trials of complex interventions. Stat Methods Med Res 2010;19(3): 237-270.

22. 22. Nistiar F, Racz O, Lukacinova A, Hubkova B, Novakova J, Lovasova E, Sedlakova E. Age dependency on some physiological and biochemical parameters of male Wistar rats in controlled environment. J Environ Sci Health A Tox Hazard Subst Environ Eng 2012; 47(9): 12241233.

23. 23. Zaidi M, Lizneva D, Kim SM, Sun L, Iqbal J, New MI., Rosen CJ, Yuen T FSH, Bone Mass, Body Fat, and Biological Aging. Endocrinology 2018; [Epub ahead of print]

24. Sutherland MR, Béland C, Lukaszewski M, Cloutier A, Bertagnolli M, Nuyt AM.Age and sex related changes in rat renal function and pathology following neonatal hyperoxia exposure. Physiol Rep 2016;4(15): e12887-12898. 
25. Johnson S, Rishi R, Andone A, Khawandi W, Alsaid J, Glestumiller N, Lin E, Baumgarten DA, ONeil WC .Determinants and functional significance of renal parenchymal volume in adults. Clin J Am Soc Nephrol 2011; 6 (1): 70-76.

26. Wang X, Vrtiska TJ, Avula RT, Walters LR, Chakkera HA, Kremers WK, Lerman LO, Rule AD. Age, kidney function, and risk factors associate differently with cortical and medullary volumes of the kidney. Kidney Int 2014; 85(3): 677-685.

27. Baxmann AC, Ahmed MS, Marques NC, Menon VB, Pereira AB, Kirsztajn GM, Heilberg IP. Influence of muscle mass and physical activity on serum and urinary creatinine and serum cystatin. C Clin J Am Soc Nephrol 2008; (3): 348-354 .

28. Black MJ, Lim K, Zimanyi MA, Sampson AK, Bubb KJ, Flower RL, Parkington HC, Tare M, Denton KM. Accelerated age-related decline in renal and vascular function in female rats following early-life growth restriction. Am J Physiol Regul Integr Comp Physiol 2015; 309 (9):1153-1161.

29. Leh S, Hultström M, Rosenberger C, Iversen BM .Afferent arteriolopathy and glomerular collapse but not segmental sclerosis induce tubular atrophy in old spontaneously hypertensive rats. Virchows Arch 2011; 459(1): 99-108.

30. Yabuki A, Yoneshige S, Tanaka S, Tsujio M, Mitani S, Yamato O. Age-Related Histological Changes in Kidneys of Brown Norway Rat. J Vet Med Sci 2014; 76(2): 277-280 .

31. Zhao J, Cheng Q, Ye P, Yang G, Liu S, Ao Q, Liu Y, $\mathrm{Hu}$ Y. Atorvastatin improves pathological changes in the aged kidney by upregulating peroxisome proliferator-activated receptor expression and reducing matrix metalloproteinase- 9 and transforming growth factor- $\beta 1$ levels. Exp Gerontol 2016; 74: 37-42 .

32. Glassock RJ, Rule AD. The implications of anatomical and functional changes of the aging kidney: with an emphasis on the glomeruli. Kidney Int 2012; 82: 270-277.

33. Wang X, Bonventre JV, Parrish AR. The Aging Kidney: Increased Susceptibility to Nephrotoxicity. Int J Mol Sci 2014; 15(9): 15358-15376.

34. Tavano-Colaizzi L, López-Teros M, PérezLizaur AB, Martínez-Castro N, Isoard-Acosta F, Hernández-Guerrero $\mathrm{C}$. The consumption of antioxidants protects against cognitive and physical disabilities in aged with obesity. Nutr Hosp 2018; 35(4): 811-819 (Abstract).
35. Lu P, Takai K, Weaver VM, Werb Z .Extracellular matrix degradation and remodeling in development and disease. Cold Spring Harb Perspect Biol 2011;3(12): a005058-005081.

36. Oelusarz A, Nichols LA, GrunzBorgmann EA, Chen G, Akintola AD, Catania JM, Burghardt RC, Trzeciakowski JP, Parrish AR. Overexpression of MMP7 Increases Collagen 1A2 in the Aging Kidney. Physiol Rep 2013; (5): e90-109.

37. Arai KY, Hara T, Nagatsuka T, Kudo C, Tsuchiya S, Nomura Y, NishiyamaT. Postnatal changes and sexual dimorphism in collagen expression in mouse skin. Plos One 2017; 12(5): e01775340177554 .

38. Son ED, Lee JY, Lee S, Kim MS, Lee BG, Chang IS, Chung JH Topical application of 17betaestradiol increases extracellular matrix protein synthesis by stimulating tgf-Betasignaling in aged human skin in vivo. J Invest Dermatol 2005; 124(6): 1149-1161.

39. Terrell SP, Origgi FC, Agnew D. Glomerulonephropathy in aged captive Key Largo woodrats (Neotoma floridana smalli). Vet Pathol 2012; 49(4): 710-716.

40. Chen D, Tang Z, Luo C, Chen H, Liu Z. Clinical and pathological spectrums of aristolochic acid nephropathy. Clin Nephrol 2012;78(1): 54-60.

41. Lin IH, Chang JL, Hua K, Huang WC, Hsu MT, Chen YF. Skeletal muscle in aged mice reveals extensive transformation of muscle gene expression. BMC Genet 2018; 19(1): 55.

42. Boyce RW, Brown D, Felx M, Mellal N, Locher K, Pyrah I, Ominsky MS, Taylor S. Decreased osteoprogenitor proliferation precedes attenuation of cancellous bone formation in ovariectomized rats treated with sclerostin antibody. Bone Rep 2018; 8: 90-94.

43. Thomasova D, Anders HJ .Cell cycle control in the kidney. Nephrol Dial Transplant 2015; (10): 16221630 .

44. Jiang D, Xu B, Gao P. Effects of young extracellular matrix on the biological characteristics of aged tendon stem cells. Adv Clin Exp Med 2018; [Epub ahead of print].

45. Li KL, Wang JM, Ding HL, Zhao L, Song RH, Chen L, Li KL, Wang JM, Ding HL, Zhao L et al .Effect of p21 on the changes in renal tubular epithelial cells after ischemia $\backslash$ reperfusion injury of kidney. Zhongguo Wei Zhong Bing Ji Jiu Yi Xue 2005;17(10): 606-610 (Abstract). 
46. Li S, Huang KJ, Wu JC, Hu MS, Sanyal M, Hu M, Longaker MT, Lorenz HP. Peripheralbloodderived mesenchymal stem cells: candidate cells responsible for healing critical-sized calvarial bone defects. Stem Cells Transl Med 2015;4(4): 359-368.

47. Wangers AJ. The stem cell niche in regenerative medicine. Cell Stem Cell 2012; 10: 362-369.

48. Miller FD, Kaplan DR. Mobilizing endogenous stem cells for repair and regeneration: are we there yet? Cell Stem Cell 2012; 10(6): 650-652 .
49. Kisday JD, Schwartz JA, Tangtrongsup S, Goodrich LR, Grande DA. Culture Conditions that Support Expansion and Chondrogenesis of Middle-Aged Rat Mesenchymal Stem Cells. Cartilage 2018; [Epub ahead of print]

50. Song HF, He S, Li SH, Yin WJ, Wu J, Guo J, Shao ZB, Zhai XY, Gong H, Lu L et al . Aged Human Multipotent Mesenchymal Stromal Cells Can Be Rejuvenated by Neuron-Derived Neurotrophic Factor and Improve Heart Function After Injury. JACC Basic Transl Sci 2017; 2(6): 702-716. 


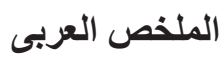

\section{علافة التغيرات الهيكلية بلقشرة الكلوية باختلاف الجنس فى مختلف الفئات العمرية والدور الوقائى المحتمل للخلايا الجذعية}

\section{مها بليخ ذكري ‘,'، أماني السيد حمود؟}

قسم الأنسجة الطبية وبيولوجيا الخلية'، قسم الثشريح'، كلية الطب، جامعة القاهرة

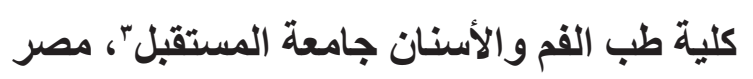

خلفية: مرض الكلى المزمن قد يسبب الوفاة فى مرحلة الثيخوخة. وفى بعض الاحيان يكون نسبة اصابة الذكور أعلى منها فى الإناث. انقسام الخلايا الجذعية والذى ينشط عند حدوث الإصابة مما يؤدى إلى إعادة بناء الخلية.

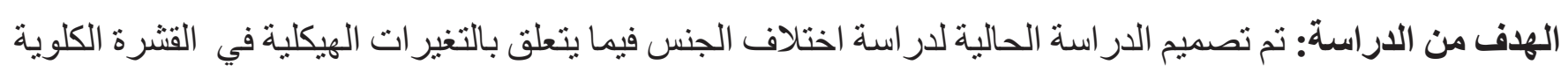
فى مختلف الفئات العمرية قبل سن البلوغ والبلوغ وما بعد البلوغ فى الفئر ان. بالإضافة إلى ذلك الدور المحتمل للخلايا الجذعية فى علاج مثل هذة التغير ات. المواد والطرق: تم تقسيم ثلاثثين فأر ا من فئر ان الألبينو إلى ثلاث مجمو عات: قبل البلوغ، البلوغ غيلو وما بعد البلوغ. وحيث تنقسم كل مجمو عة إلى مجمو عتين فر عيتين من الذكورو الإناث على التو الي .وتم حساب وزن الجسم ووزن الكلى ونسبة الكرياتينين فى الدم وقد تم فحص عينات الكل بالنسيجية و المناعية، وتم عمل الدر اسات المورفومترية والإحصائية.

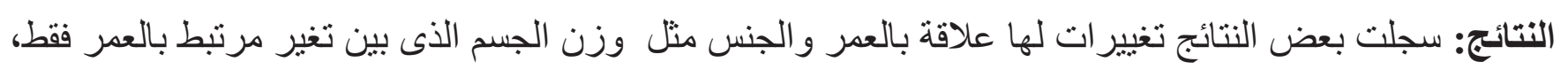
بينما وزن الجسم ونسبة الكرياتينين وسمك الغشاء القاعدى و عدد الخلايا التالفة اوضحت تغيير مرتبط بالجنس و السن. الخلاصة: تم الوصول على ان زيادة وزن الجسم ووزن الكلى ونسبة الكرياتين مرتبط بالتقدم في العمر ، بينما زيادة نسبة تليف الخلاياوسمك الغشاء القاعدى بينماوزن الجسم ونسبة الكرياتينين و عدد الخلايا التالفة اوضحت تغييرمرتبط بالجنس والسن. امـا زيادة نسبة الخلايا الجذعية فكان اكثر وضوحا فى الذكور عنة فى الإناث فى المراحل العمرية المتقدمة. 